\title{
Effect of a lung rest strategy during ECMO in a porcine acute lung injury model
}

\author{
J Araos ${ }^{1}$, P Cruces ${ }^{2,3}$, P Tapia ${ }^{1}$, L Alegria ${ }^{1}$, P García ${ }^{1}$, T Salomon $^{4}$, F Rodriguez ${ }^{1}$, M Amthauer ${ }^{1}$, G Castro ${ }^{1}$, B Erranz ${ }^{5}$, \\ D Soto ${ }^{1}$, P Carreño ${ }^{3}$, T Medina $^{3}$, F Damiani $^{1}$, G Bugedo ${ }^{1}$, A Bruhn $^{1 *}$ \\ From ESICM LIVES 2015 \\ Berlin, Germany. 3-7 October 2015
}

\section{Introduction}

ECMO is used to treat patients who develop refractory hypoxemia and to provide a more protective ventilation. Several guidelines recommend "lung rest" strategies based on variable ventilatory parameters. However, there is limited evidence to support this strategy.

\section{Objectives}

To compare the effect of a lung rest strategy based on near-apneic ventilation (Vt 1-2 ml/kg, PEEP 10, respiratory rate - RR $5 \mathrm{~min}$ ) versus conventional ( $\mathrm{Vt} 10 \mathrm{ml} / \mathrm{kg}$, PEEP 5, RR 20/min), and standard protective ventilation (Vt $6 \mathrm{ml} / \mathrm{kg}$, PEEP 10, RR 20/min).

\section{Methods}

Twenty-four domestic pigs $(26-36 \mathrm{~kg})$ were anesthetized, mechanically ventilated (Vt $10 \mathrm{ml} / \mathrm{kg}$, PEEP 5, O2 1.0) and invasively monitored. Six animals were used as Sham. In the other 18 lung injury was induced by saline lavages (30 $\mathrm{ml} / \mathrm{kg}$ per lavage) performed repeatedly in both supine and prone position until $\mathrm{PaO} 2 / \mathrm{FiO} 2$ dropped below 250. They were then subjected to a 2-hour injurious ventilation with PCV, PEEP $=0$, Pinsp = $40 \mathrm{cmH} 2 \mathrm{O}, \mathrm{RR}=10 / \mathrm{min}, \mathrm{I}: \mathrm{E}=1: 1$, one hour in prone and the other in supine. After completing lung injury (time 0) animals were connected to a saline primed-MEDOS Hilite ECMO circuit by inserting a AVALON 23F double-lumen cannula through the external jugular vein. Blood flow was set at $60-70 \%$ of cardiac output. Animals were randomized into one of the three groups and ventilated according to randomization for the following 24 hours. Respiratory and hemodynamic data were collected at times $0,3,6,12,18$ and $24 \mathrm{~h}$. After euthanizing animals at time $24 \mathrm{~h}$, tissue

Pontificia Universidad Catolica de Chile, Departamento de Medicina Intensiva, Santiago, Chile

Full list of author information is available at the end of the article samples were extracted from the lungs and injury evaluated and scored by light microscopy. Total lung water content was estimated by the wet-dry weight ratio.

\section{Results}

$\mathrm{PaO} 2$ decreased significantly in all groups after injury, but was progressively restored after ECMO start, despite the study group. Mean arterial pressure remained within normal limits throughout the study period, whereas MPAP increased significantly after injury but reached values close to SHAM soon after ECMO initiation. Lung wet-dry weight ratio and histological injury score increased significantly in all study groups compared to SHAM. Although non-significant, there was a trend towards a better histological injury score when Vt was reduced.

\section{Conclusions}

In this preliminary analysis, we found no clear advantage of reducing Vt when applying ECMO to support a double-hit animal model of ARDS in regard to resolution of lung edema or gas exchange. However, further work is required to determine if the non-significant reduction in lung injury observed in the near-apneic strategy may be relevant in providing further protection to the injured lungs supported by ECMO.

\section{Grant Acknowledgment \\ CONICYT, Fondecyt 1130428.}




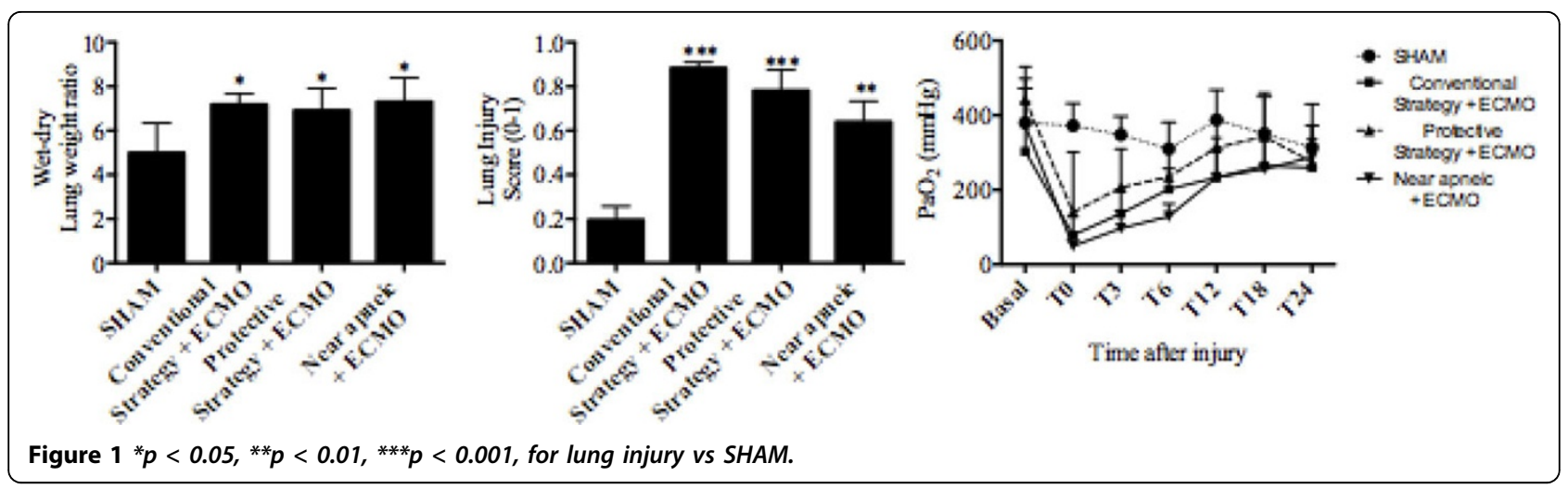

Published: 1 October 2015

\section{Reference}

1. Gattinoni L, Carlesso E, Langer T: Towards ultraprotective mechanical ventilation. Curr Opin Anesthesiol 2012, 25(2):141-147.

doi:10.1186/2197-425X-3-S1-A503

Cite this article as: Araos et al:: Effect of a lung rest strategy during

ECMO in a porcine acute lung injury model. Intensive Care Medicine Experimental 2015 3(Suppl 1):A503.

Submit your manuscript to a SpringerOpen ${ }^{\mathcal{O}}$ journal and benefit from:

- Convenient online submission

- Rigorous peer review

- Immediate publication on acceptance

- Open access: articles freely available online

- High visibility within the field

- Retaining the copyright to your article

Submit your next manuscript at $>$ springeropen.com 